\title{
Untreated Childhood Pleomorphic Xanthoastrocytoma
}

National Cancer Institute

\section{Source}

National Cancer Institute. Untreated Childhood Pleomorphic Xanthoastrocytoma. NCI

Thesaurus. Code C115953.

A finding of pleomorphic xanthoastrocytoma in childhood that has not been treated. 